Case Report

\title{
Spontaneous hemangioendothelial cell hyperplasia of the heart in a young ICR mouse
}

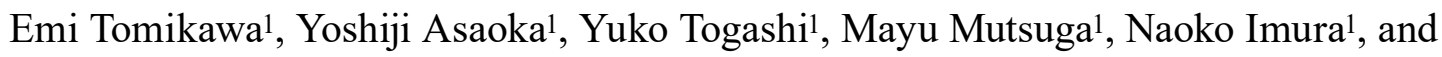 \\ Keiyu Oshida ${ }^{*}$ \\ ${ }^{1}$ Toxicology and Pharmacokinetics Laboratories, Pharmaceutical Research Laboratories, Toray Industries, Inc., 10-1 Tebiro 6-chome, \\ Kamakura, Kanagawa 248-8555, Japan
}

\begin{abstract}
Spontaneous nonneoplastic proliferative lesions of the cardiac hemangioendothelium are extremely rare in humans and animals. Here, we describe a spontaneous hemangioendothelial cell hyperplasia in the heart of a 9-week-old male ICR mouse. The lesion was observed focally in the interventricular septum, with no compression of the surrounding tissues. In the lesion, a single layer of hemangioendothelial cells that had a polygonal shape with enlarged nuclei and plump cytoplasm closely lined surrounding widened capillary vascular spaces and cardiac muscles. There was little cellular atypia, and there were no multilayered endothelial cells. Immunohistochemical staining revealed that these cells were partly positive for factor VIII and CD31, hemangioendothelial cell markers, and negative for $\mathrm{Ki}-67$. These features were consistent with those in aged female $\mathrm{B}_{6} \mathrm{C}_{3} \mathrm{~F}_{1}$ mice in the only report in mice of spontaneous cardiac hemangioendothelial cell hyperplasia. Therefore, this is the first report of spontaneous hemangioendothelial cell hyperplasia in the heart of a young mouse. (DOI: 10.1293/tox.2019-0008; J Toxicol Pathol 2019; 32: 289-292)
\end{abstract}

Key words: hemangioendothelial cell hyperplasia, young mouse, Crl:CD1(ICR), heart, spontaneous

Hemangioendothelial cell hyperplasia, a nonneoplastic proliferative lesion, is induced by chemicals such as 1,3-butadienel-3, captafol $^{4}$, and PPAR agonist ${ }^{5}$. However, this lesion rarely occurs spontaneously in humans ${ }^{6-11}$ and animals ${ }^{12-14}$. In the mouse heart, there is only one report of hemangioendothelial cell hyperplasia, a report in aged female $\mathrm{B} 6 \mathrm{C} 3 \mathrm{~F}_{1}$ mice with mammary adenocarcinomas ${ }^{14}$. Here, we describe the pathological features of spontaneous hemangioendothelial cell hyperplasia in the heart of a young male ICR mouse.

The animal was a 9-week-old male ICR [Crl:CD1(ICR)] mouse (Charles River Laboratories Japan, Inc., Kanagawa, Japan) orally treated with water for 14 days in the control group of a toxicity study. The mouse was housed in a plastic cage with softwood chip bedding under controlled conditions (12 h light/dark cycle, $40-70 \%$ humidity at $21-25^{\circ} \mathrm{C}$ ) and fed a standard diet (CRF-1, Oriental Yeast Co., Ltd., Tokyo, Japan) and tap water ad libitum. This study was reviewed and approved by the head of the test facility and

Received: 22 January 2019, Accepted: 7 May 2019

Published online in J-STAGE: 9 June 2019

*Corresponding author: K Oshida

(e-mail: keiyu.oshida.h5@mail.toray)

(C2019 The Japanese Society of Toxicologic Pathology

This is an open-access article distributed under the terms of the Creative Commons Attribution Non-Commercial No Derivatives (by-nc-nd) License. (CC-BY-NC-ND 4.0: https:// creativecommons.org/licenses/by-nc-nd/4.0/) performed in accordance with the Guidelines for Animal Experiments, Research \& Development Division, Toray Industries, Inc.

The animal had no abnormalities in clinical signs, body weight, hematology, blood chemistry, organ weight, or necropsy findings. The histopathological lesion was only observed in the heart; it was not observed in any other organs in this animal. The heart of the animal was routinely fixed in $10 \%$ neutral buffered formalin, trimmed longitudinally, embedded in paraffin, and sectioned. Sections were stained with hematoxylin and eosin (HE) and periodic acid Schiff (PAS). For immunohistochemical staining, a rabbit antihuman factor VIII polyclonal antibody (Biocare Medical, LLC, Concord, CA, USA) ${ }^{15}$, a rat anti-mouse CD31 monoclonal antibody (Abcam K.K., Tokyo, Japan) ${ }^{16}$, a rabbit antimouse Ki-67 polyclonal antibody (Novus Biologicals, LLC, Littleton, $\mathrm{CO}$, USA) ${ }^{17}$, a rat anti-mouse F4/80 monoclonal antibody (AbD Serotec. Ltd., Kidlington, UK) ${ }^{18}$, a goat anti-human alpha smooth muscle actin ( $\alpha$-SMA) polyclonal antibody (Abcam K.K.), and a rabbit anti-human desmin monoclonal antibody (Abcam K.K.) ${ }^{19}$ were used. For antigen retrieval, heat treatment of the sections was performed for Ki-67 and $\alpha$-SMA immunohistochemical staining, and sections were treated with protease for factor VIII, CD31, and F4/80 immunohistochemical staining. The proliferative lesion was observed in the heart of only one animal, and there was no similar lesion in the remainder of the animals examined in this study.

In the interventricular septum, the proliferative lesion 
was observed focally, and its maximal diameter was approximately $0.5 \mathrm{~mm}$. The lesion was not continuous with the epicardium or endocardium. A single layer of the cells in the lesion closely lined surrounding widened capillary vascular spaces and cardiac muscles (Fig. 1A). In the lesion, most cells were polygonal-shaped cells with enlarged nuclei and plump cytoplasm, and some cells had spindle-shaped nuclei and scant cytoplasm similar to normal endothelial cells. Although these cells in the lesion that were similar to normal endothelial cells were positive for factor VIII and $\mathrm{CD} 31$, a hemangioendothelial cell marker, the polygonalshaped cells in the lesion were negative for these markers (Fig. 2A and B). The cells in the lesion were also negative for Ki-67, a proliferating cell marker; F4/80, a macrophage marker; $\alpha$-SMA, a smooth muscle cell marker; and desmin, a muscle cell marker (Fig. 2C and F). Hemangioendothelial cell hyperplasia is diagnosed on the basis of a proliferation of small vessel endothelial cells with luminal dilation, which indicates that the lesion is hemangioendothelial hyperpla$\mathrm{sia}^{20}$. In a previous report regarding spontaneous hemangioendothelial cell hyperplasia of the heart in aged female $\mathrm{B}_{6} \mathrm{C}_{3} \mathrm{~F}_{1}$ mice, the cells in the lesion were focally positive for both factor VIII and CD31 and negative for proliferating cell nuclear antigen (PCNA) ${ }^{14}$. In the current case, the cells in the lesion were partly positive for both factor VIII and CD31 and negative for Ki-67 (Fig. 2), which is consistent with the previous report of spontaneous hemangioendothelial cell hyperplasia ${ }^{14}$.

In the differential diagnosis, hemangioma and hemangiosarcoma were considered from among the other proliferative lesions of the hemangioendothelial cell. Hemangioma is diagnosed on the basis of a moderate compression of the surrounding tissues and a single layer of prominent uniform endothelial cells without atypia ${ }^{20,21}$. In the current case, there was no compression of the surrounding tissues, and polygonal-shaped cells and normal endothelial-like cells closely lined the wide capillary vascular space in a single layer. These findings suggest that the present case does not match hemangioma. Hemangiosarcoma is diagnosed on the basis of cellular atypia and an obvious proliferation with multilayered or clustered endothelial cells ${ }^{20,21}$. In the current case, there was little cellular atypia, and there were no multilayered endothelial cells, and the lesion was focal, indicating that the lesion was not a hemangiosarcoma. There-

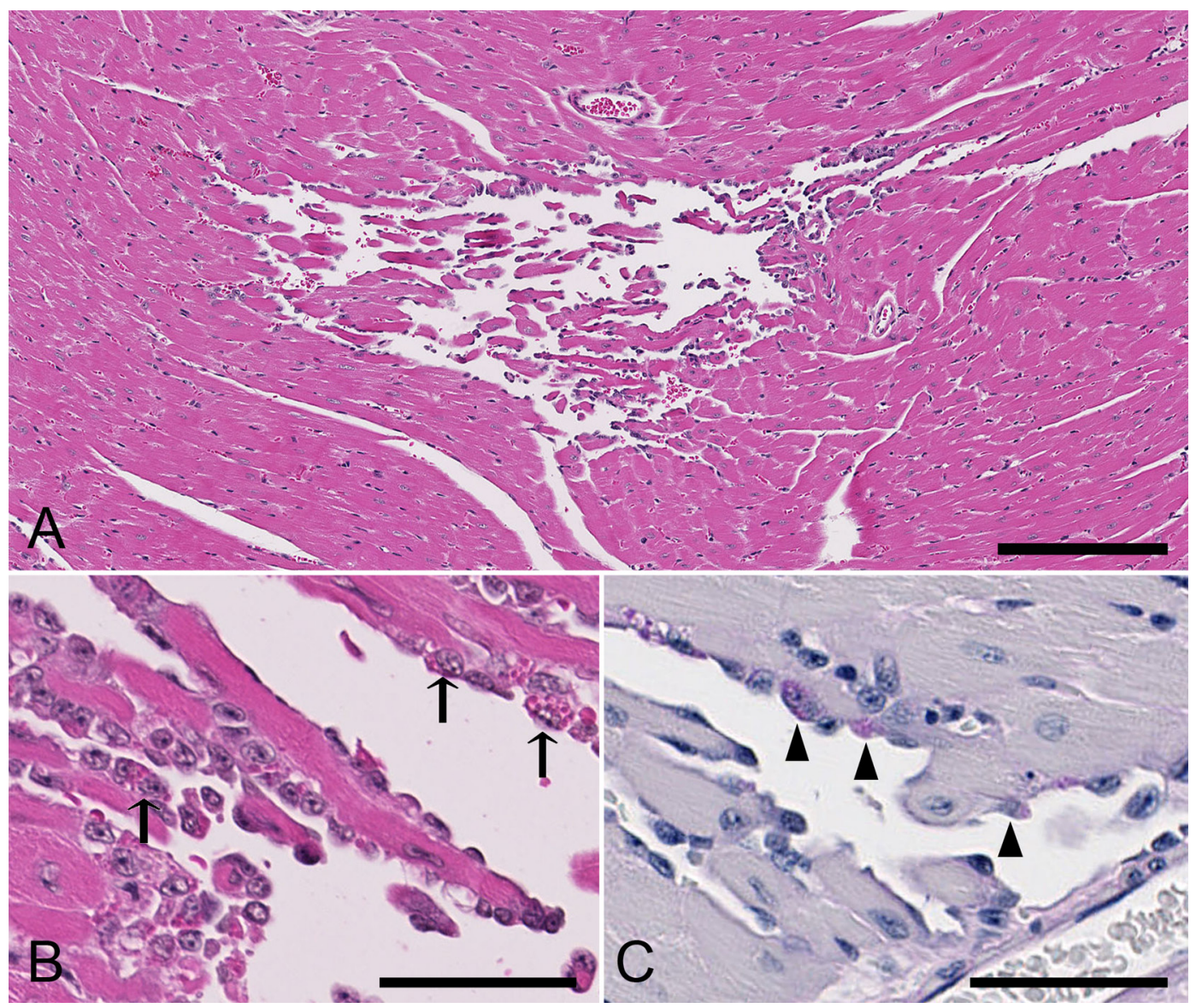

Fig. 1. Histopathological features in the heart of a young ICR mouse. (A) A single layer of hemangioendothelial cells closely lined surrounding widened capillary vascular spaces and cardiac muscles in the interventricular septum adjacent to the left ventricle. (B, C) Part of the cells included eosinophilic granules (B, arrows), which were PAS positive (C, arrowheads). Hematoxylin and eosin staining (A, B) and periodic acid Schiff (PAS) staining (C). Bars: $200 \mu \mathrm{m}(\mathrm{A}), 50 \mu \mathrm{m}(\mathrm{B}, \mathrm{C})$. 
fore, we concluded that the present case was a case of hemangioendothelial cell hyperplasia.

Some of the polygonal-shaped cells were more enlarged than other cells in the lesion and included eosinophilic droplets in the cytoplasm, which were positive for PAS staining (Fig. 1B and C). Hemangioendothelial cells have a highly developed system of cell membrane vesicles to transport macromolecules, such as albumin, from the bloodstream to tissue spaces $22-24$. These vesicles accumulate and fuse in hypertrophied endothelial cells in vascular diseases such as cardiac hypertrophy, dyslipidemia, and hyperglycemia ${ }^{25,26 .}$ Eosinophilic globules are a commonly seen histological feature in pyogenic granuloma, granulation tissue, and various hemangioendothelial tumors such as glomeruloid hemangioma, papillary hemangioma, and Kaposi's sarcoma ${ }^{27-29}$. One hypothesis for this is that eosinophilic globules are formed due to an impaired lysosomal degradation process in injured cells demonstrating membrane blebbing, increased influx of plasma proteins, and increased autophagocytic activity 27,28 . Therefore, the eosinophilic droplets may have resulted from the accumulation and fusion of cell membrane vesicles.

Spontaneous cardiac endothelial cell hyperplasia is associated with thrombi of the atrium and ventricle in humans $^{9,}{ }^{10}$. In aged mice with adenocarcinomas of the mam- mary gland, spontaneous cardiac endothelial cell hyperplasia is diffusely observed with little mitosis at 86 to 109 weeks old and is considered to be related to female sex hormones and humoral endothelial cell growth factors produced by mammary tumors ${ }^{14}$. On the other hand, chemically-induced cardiac endothelial cell hyperplasia is observed at earlier ages, and it has a more focal/multifocal distribution pattern and shows prominent mitoses ${ }^{1-5}, 14$. In the current case, the lesion was focally observed at 9 weeks old without high proliferation activity such as increases in mitosis and cells positive for Ki-67 immunohistochemical staining, suggesting that the current case cannot be categorized according to previous reports ${ }^{1-5,14}$. We could not determine the pathogenesis of the hyperplasia because no other lesions were observed in the heart or other organs.

In conclusion, we found spontaneous endothelial cell hyperplasia of capillaries in the heart of a 9-week-old male ICR mouse. The observations reported here may be useful for evaluating cardiac proliferative lesions in carcinogenicity and/or general toxicity studies.

Disclosure of Potential Conflicts of Interest: The authors have no conflicts of interest in connection with this paper.

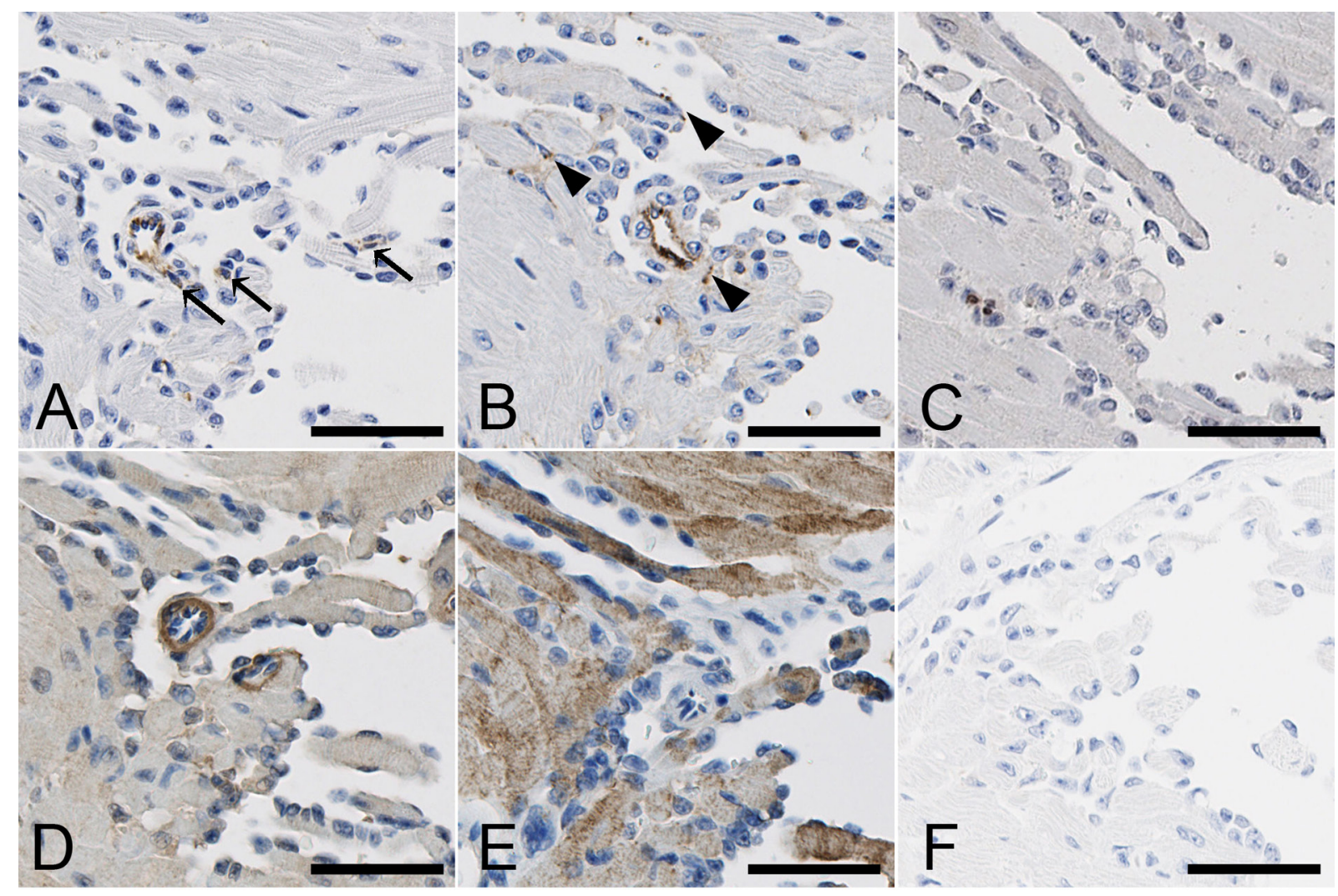

Fig. 2. Immunohistochemistry in the heart of a young ICR mouse. Hemangioendothelial cells in the lesion were partly positive for CD31 (A, arrows) and factor VIII (B, arrowheads) and negative for Ki-67 (C), $\alpha$-SMA (D), desmin (E), and F4/80 (F). Bar: $50 \mu \mathrm{m}$. 


\section{References}

1. Miller RA, and Boorman GA. Morphology of neoplastic lesions induced by 1,3-butadiene in $\mathrm{B}_{6} \mathrm{C}_{3} \mathrm{~F}_{1}$ mice. Environ Health Perspect. 86: 37-48. 1990. [Medline]

2. Solleveld HA, Miller RA, Banas DA, and Boorman GA. Primary cardiac hemangiosarcomas induced by 1,3-butadiene in B6C3F1 hybrid mice. Toxicol Pathol. 16: 46-52. 1988. [Medline] [CrossRef]

3. Melnick RL, Huff J, Chou BJ, and Miller RA. Carcinogenicity of 1,3-butadiene in $\mathrm{C} 57 \mathrm{BL} / 6 \times \mathrm{C} 3 \mathrm{H} \mathrm{F}_{1}$ mice at low exposure concentrations. Cancer Res. 50: 6592-6599. 1990. [Medline]

4. Ito N, Ogiso T, Fukushima S, Shibata M, and Hagiwara A. Carcinogenicity of captafol in B6C3F1 mice. Gan. 75: 853-865. 1984. [Medline]

5. Hardisty JF, Elwell MR, Ernst H, Greaves P, KolendaRoberts H, Malarkey DE, Mann PC, and Tellier PA. Histopathology of hemangiosarcomas in mice and hamsters and liposarcomas/fibrosarcomas in rats associated with PPAR agonists. Toxicol Pathol. 35: 928-941. 2007. [Medline] [CrossRef]

6. Guledgud MV, Patil K, Saikrishna D, Madhavan A, and Yelamali T. Intravascular papillary endothelial hyperplasia: diagnostic sequence and literature review of an orofacial lesion. Case Rep Dent. 2014: 934593. 2014. [Medline]

7. Akdur NC, Donmez M, Gozel S, Ustun H, and Hucumenoglu S. Intravascular papillary endothelial hyperplasia: histomorphological and immunohistochemical features. Diagn Pathol. 8: 167. 2013. [Medline] [CrossRef]

8. Oza A, Moreno B, Sheikh MM, and Demos TC. Magnetic resonance imaging of right ventricular papillary endothelial hyperplasia. J Thorac Imaging. 27: W2-W4. 2012. [Medline] [CrossRef]

9. Kan CD, Yae CT, and Yang YJ. Left ventricular haemangioma with papillary endothelial hyperplasia and liver involvement. Heart. 90: e49. 2004. [Medline] [CrossRef]

10. Modi A, Moorjani N, Pontefract D, and Livesey S. Isolated papillary endothelial hyperplasia in the left atrial appendage. Interact Cardiovasc Thorac Surg. 7: 1204-1206. 2008. [Medline] [CrossRef]

11. Abad C, Campo E, Estruch R, Condom E, Barriuso C, Tassies D, and Paré JC. Cardiac hemangioma with papillary endothelial hyperplasia: report of a resected case and review of the literature. Ann Thorac Surg. 49: 305-308. 1990. [Medline] [CrossRef]

12. Gamlem H, and Nordstoga K. Canine vascular neoplasia -histologic classification and immunohistochemical analysis of 221 tumours and tumour-like lesions. APMIS. 116: 19-40. 2008. [CrossRef]

13. Fuji RN, Patton KM, Steinbach TJ, Schulman FY, Bradley GA, Brown TT, Wilson EA, and Summers BA. Feline systemic reactive angioendotheliomatosis: eight cases and literature review. Vet Pathol. 42: 608-617. 2005. [Medline] [CrossRef]

14. Iwata H, Nomura $\mathrm{Y}$, and Enomoto M. Spontaneous hemangioendothelial cell hyperplasia of the heart in $\mathrm{B} 6 \mathrm{C} 3 \mathrm{~F}_{1}$ female mice. Toxicol Pathol. 22: 423-429. 1994. [Medline] [CrossRef]
15. Kao S, Mo J, Baird A, and Eliceiri BP. Basic fibroblast growth factor in an animal model of spontaneous mammary tumor progression. Oncol Rep. 27: 1807-1814. 2012. [Medline]

16. Andersson-Sjöland A, Karlsson JC, and Rydell-Törmänen K. ROS-induced endothelial stress contributes to pulmonary fibrosis through pericytes and Wnt signaling. Lab Invest. 96: 206-217. 2016. [Medline] [CrossRef]

17. Furukawa S, Nagaike M, and Ozaki K. Databases for technical aspects of immunohistochemistry. J Toxicol Pathol. 30: 79-107. 2017. [Medline] [CrossRef]

18. Liu Y, Chen Y, Liu FQ, Lamb JR, and Tam PK. Combined treatment with triptolide and rapamycin prolongs graft survival in a mouse model of cardiac transplantation. Transpl Int. 21: 483-494. 2008. [Medline] [CrossRef]

19. Lu L, Kingdom J, Burton GJ, and Cindrova-Davies T. Placental stem villus arterial remodelling associated with reduced hydrogen sulphide synthesis contributes to human fetal growth restriction. Am J Pathol. 187: 908-920. 2017. [Medline] [CrossRef]

20. Berridge BR, Mowat V, Nagai H, Nyska A, Okazaki Y, Clements PJ, Rinke M, Snyder PW, Boyle MC, and Wells MY. Non-proliferative and proliferative lesions of the cardiovascular system of the rat and mouse. J Toxicol Pathol. 29(Suppl): 1S-47S. 2016. [Medline] [CrossRef]

21. Thoolen B, Maronpot RR, Harada T, Nyska A, Rousseaux C, Nolte T, Malarkey DE, Kaufmann W, Küttler K, Deschl U, Nakae D, Gregson R, Vinlove MP, Brix AE, Singh B, Belpoggi F, and Ward JM. Proliferative and nonproliferative lesions of the rat and mouse hepatobiliary system. Toxicol Pathol. 38(Suppl): 5S-81S. 2010. [Medline] [CrossRef]

22. Ghitescu L, and Bendayan M. Transendothelial transport of serum albumin: a quantitative immunocytochemical study. J Cell Biol. 117: 745-755. 1992. [Medline] [CrossRef]

23. Gottlieb AI, Langille BL, Wong MKK, and Kim DW. Structure and function of the endothelial cytoskeleton. Lab Invest. 65: 123-137. 1991. [Medline]

24. Ackermann MR, Brogden KA, Meador VP, Meehan JA, and Sacco RE. Endothelium. In: Ultrastructural Pathology: the Comparative Cellular Basis of Disease, 2nd ed. NF Cheville (ed). Wiley-Blackwell, Iowa. 201-228. 2009.

25. Nerem RM, and Girard PR. Hemodynamic influences on vascular endothelial biology. Toxicol Pathol. 18: 572-582. 1990. [Medline]

26. Simionescu M. Implications of early structural-functional changes in the endothelium for vascular disease. Arterioscler Thromb Vasc Biol. 27: 266-274. 2007. [Medline] [CrossRef]

27. Sun K, Wei JF, Zhao M, and Teng XD. Anastomosing hemangioma of the liver containing eosinophilic hyaline globules. Int J Clin Exp Med. 10: 7291-7295. 2017.

28. Papadimitriou JC, Drachenberg CB, Brenner DS, Newkirk C, Trump BF, and Silverberg SG. "Thanatosomes": a unifying morphogenetic concept for tumor hyaline globules related to apoptosis. Hum Pathol. 31: 1455-1465. 2000. [Medline] [CrossRef]

29. Fukunaga M, and Silverberg SG. Hyaline globules in Kaposi's sarcoma: a light microscopic and immunohistochemical study. Mod Pathol. 4: 187-190. 1991. [Medline] 